\title{
T-Box Transcription Factor TBX4
}

National Cancer Institute

\section{Source}

National Cancer Institute. T-Box Transcription Factor TBX4. NCI Thesaurus. Code C106323.

T-box transcription factor TBX4 (545 aa, $60 \mathrm{kDa}$ ) is encoded by the human TBX4 gene.

This protein plays a role in both limb formation and transcriptional regulation. 